Gut, 1977, 18, 821-826

\title{
Effect of histamine receptor antagonists on bile damage to the gastric mucosa of canine Heidenhain pouches
}

\author{
W. D. W. REES, J. RHODES, M. H. WHEELER, E. M. MEEK, \\ B. WILLIAMS, AND R. G. NEWCOMBE
}

From the Departments of Gastroenterology, Surgery, and Medical Statistics of the University Hospital of Wales, and the Department of Pharmacy, University of Wales Institute of Science and Technology, Cardiff

SUMMARY The net ionic fluxes of $\mathrm{H}^{+}$and $\mathrm{Na}^{+}$were examined in Heidenhain pouches during damage with sodium taurocholate solution. The increase in ionic flux which occurred with taurocholate could be prevented in animals given $\mathrm{H}_{1}$ and $\mathrm{H}_{2}$ histamine antagonists in combination. The results suggest that histamine mediates changes in the transmucosal ionic flux produced by bile acid.

Although it is well recognised that damaged gastric mucosa becomes more permeable to both hydrogen and sodium ions, the mechanisms involved are poorly understood. Davenport (1972) suggested that the surface lipoprotein layer of gastric epithelium was the major constituent of the mucosal barrier, and disruption of this layer facilitated back diffusion of hydrogen ions which in turn caused release of histamine from mast cells. Support for this hypothesis was provided by Johnson $(1966,1968)$ who used the pylorus-ligated stomach in rats to show that mucosal damage resulted in histamine release, which did not occur if the mast cells of these animals were first degranulated with compound 48/80. Davenport suggested that the histamine produced vasodilatation, increased capillary permeability and mucosal oedema; the increased flux of a sodium rich fluid into the lumen was thought to be the result of these changes. Complementary findings were made by Guth and Hall (1966) who showed in stressed rats that gastric mucosal damage was associated with vascular engorgement and degranulation of mucosal mast cells; they proposed that stress released vasoactive substances from mast cells which caused the vascular changes.

Several authors have shown that histamine causes gastric mucosal vasodilatation with an increased mucosal blood flow (Jacobson and Chang, 1969; Augur, 1970; Reed and Smy, 1971; Reed and Sanders, 1975) but the effect of histamine on ionic diffusion is less well defined. Moody and Davis

Received for publication 18 February 1977
(1970) used sodium thiocyanate to inhibit gastric acid secretion and showed that intravenous histamine produced marked reciprocal exchange of hydrogen for sodium ions with disruption of the epithelium in canine stomachs. Fromm and coworkers (1975), however, using an in vitro gastric mucosal preparation showed that histamine applied topically reduced the ionic diffusion produced by salicylate.

The discovery of two types of histamine receptor by Black and co-workers (1972) has reawakened interest in the role of histamine in gastric physiology. Both types of receptor are found in the cardiovascular system where they are responsible for mediating the vasodilator and hypotensive actions of histamine (Black et al., 1975; Flynn and Owen, 1975).

In the stomach, $\mathrm{H}_{2}$ receptors are associated with parietal cells, while both $\mathrm{H}_{1}$ and $\mathrm{H}_{2}$ receptors are present on blood vessels. The aim of the present study was to determine the effect of combined $\mathrm{H}_{1}$ and $\mathrm{H}_{2}$ histamine receptor antagonism on damage to the gastric mucosal barrier produced by sodium taurocholate.

\section{Methods}

Four mongrel dogs were prepared with gastric Heidenhain pouches and experiments started two months later. The experiments were similar to Davenport's and included three 30-minute periods during which solutions were placed in the pouch and changes in the volume and ionic $\left(\mathrm{H}^{+}\right.$and $\left.\mathrm{Na}^{+}\right)$ 
concentrations determined; the transmucosal potential difference was recorded simultaneously. In periods I and III a standard acid solution containing $100 \mathrm{mM} \mathrm{HCl}$ was used and in period II a taurocholate solution containing the same $\mathrm{H}^{+}$concentration.

Period I served as a control period and period III was used to assess recovery of the mucosa after exposure to taurocholic acid.

Four series of experiments were carried out in a random order, during which animals were given $\mathrm{H}_{1}$ and $\mathrm{H}_{2}$ receptor antagonists, alone and in combination; during the control experiments an intravenous infusion of normal saline $(50 \mathrm{ml} / \mathrm{h})$ was given. The $\mathrm{H}_{2}$ antagonist metiamide was given intravenously $(200 \mu \mathrm{mol} / 50 \mathrm{ml} / \mathrm{h}$ throughout the experiment and the $\mathrm{H}_{1}$ antagonist mepyramine maleate intravenously during period $\mathrm{I}(10 \mathrm{mg} / \mathrm{kg}$ in saline). Each experiment was repeated three times in each dog and all experiments were carried out over a 10 week period. The effect of these drugs on the damage produced by taurocholate was assessed by comparison with control experiments.

The pouch was drained by a vitallium cannula which was connected by tubing via a three-way tap (A) to a vertical open-ended tube (Fig. 1). Below the connection of the cannula and the tube a small diameter catheter and an $\mathrm{Agar} / \mathrm{KCl}$ electrode lead were inserted through the wall of the tube so that their ends were within the pouch. The other end of the catheter was connected to another three way tap (B) through which solutions were introduced into the pouch. The salt agar electrode, from the pouch, together with a second electrode inserted subcutaneously were connected via a pair

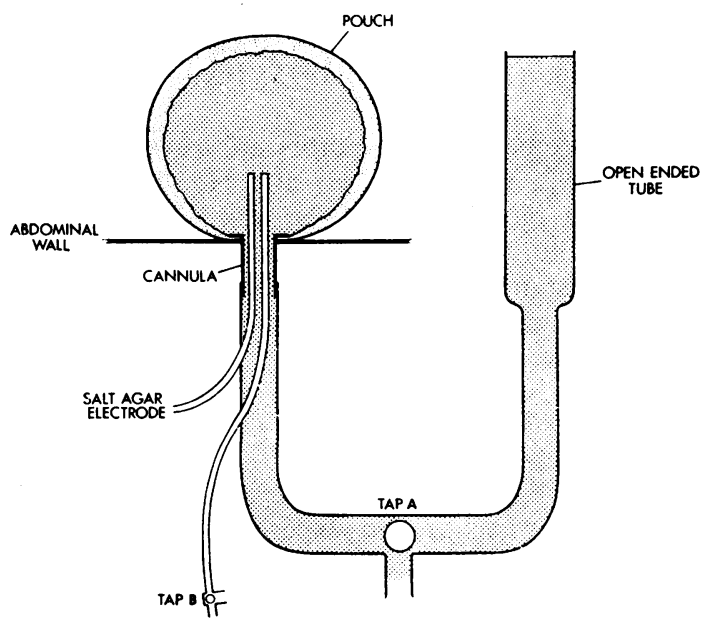

Fig. 1 The experimental model with a canine Heidenhain pouch connected by a tube to an open ended reservoir. of calomel electrodes to a direct reading $\mathrm{pH}$ meter which recorded potential difference (PD); continuous recordings of PD were made with a pen recorder.

\section{STANDARD ACID SOLUTION}

This was at $\mathrm{pH} 1.2$ and contained $100 \mathrm{mM}$ hydrochloric acid, $78 \mathrm{mM}$ mannitol, and sodium chloride, the concentration of which depended on the concentration of sodium in the taurocholate solution.

\section{TAUROCHOLATE SOLUTION}

This was at $\mathrm{pH} 1.2$ and contained $100 \mathrm{mM}$ hydrochloric acid and $78 \mathrm{mM}$ mannitol. As the concentration of taurocholate varied with each dog, the concentrations of sodium in the corresponding standard acid solutions were adjusted so that the cationic and anionic concentrations were the same in both solutions.

The concentration of taurocholate used in each dog was that which produced 'minimal' damage to the mucosal barrier and was determined by a series of preliminary experiments. In these experiments the concentration of taurocholate was adjusted by $2 \mathrm{mM}$ each time to establish the required concentration; below this concentration mucosal damage was inconsistent. The concentrations used were: dog A $12 \mathrm{mM}$; B $10 \mathrm{mM}$; C $16 \mathrm{mM}$; D $18 \mathrm{mM}$.

All the intravenous solutions were of the same ionic composition and osmolarity. The rate of infusion was constant for each of the four series of experiments and infusions were started 30 minutes before the onset of the first period. The residual volume was measured for each dog and was assumed to be constant during the experiments. The mean values and standard deviations were $\operatorname{dog} \mathrm{A} 1.40 \mathrm{ml}$ ( \pm 0.24$) ; \mathrm{B}, 1.27 \mathrm{ml}( \pm 0.35) ; \mathrm{C}, 1.75 \mathrm{ml}$ ( \pm 0.89$)$; $\mathrm{D}, 1.40 \mathrm{ml}( \pm 0.49)$.

The dogs were fasted for 18 hours before each experiment. Immediately before experiments the pouch was washed with $50 \mathrm{ml}$ of standard acid solution and drained in a standard way to ensure that the volume and composition of the residual volume was similar for each period. Sixty millilitres of standard acid solution was then injected via tap B so that fluid passed through the pouch into the circuit, mixing thoroughly with the residual volume. A $10 \mathrm{ml}$ sample was removed to measure sodium and hydrogen ion concentrations. During experiments the pressure within the pouch was kept constant by adjusting the height of the fluid column in the open-ended tube. After 30 minutes, during which time the contents of the pouch were mixed thoroughly on two occasions, the pouch was drained and the volume and ionic concentrations measured. The same procedure was repeated for each period 
with the exception that the taurocholate solution was used in period II.

Hydrogen ion concentration was determined by titrating with $0.01 \mathrm{~N} \mathrm{NaOH}$ to $\mathrm{pH} 7$ using an automatic titrator. Sodium ion concentration was measured using a flame photometer. All measurements were in duplicate and expressed as micromoles per $\mathrm{ml}$. The net fluxes of sodium and hydrogen ions were calculated from changes in ionic concentrations and volume; they are expressed as micromoles per 30 minutes. The mean potential difference for each period was calculated from the recordings and expressed in millivolts (mV). Comparisons were made between the potential difference and changes in the volume, ionic concentrations and fluxes in each of the three periods, with the control infusion, $\mathrm{H}_{2}$ infusion, $\mathrm{H}_{1}$ injection, and with $\mathrm{H}_{1}+\mathrm{H}_{2}$ antagonists in combination.

The histamine content of 24 samples of fluid drained from pouches was measured fluorometrically by the method of Shore et al. (1959). The solutions were from periods I and II in three control experiments and three using $\mathrm{H}_{1}+\mathrm{H}_{2}$ antagonists together in dogs $\mathbf{A}$ and $\mathbf{B}$. This method gave some fluorescence with solutions which had not been in the pouch, so that it was necessary to subtract these readings from values on the fluid which had drained from pouches when calculating histamine content.

\section{Results (Table, Fig. 2)}

\section{CONTROL EXPERIMENTS, AND THOSE}

WHERE EITHER H (MEPYRAMINE

MALEATE) OR $\mathrm{H}_{2}$ (METIAMIDE)

ANTAGONISTS WERE GIVEN

The results from these three sets of experiments did not differ significantly and only the values from control experiments will be quoted. During period I there was a small loss of fluid from the pouch (overall mean $-0.2 \mathrm{ml}$ ), but with bile in the pouch (period II) the volume recovered was consistently

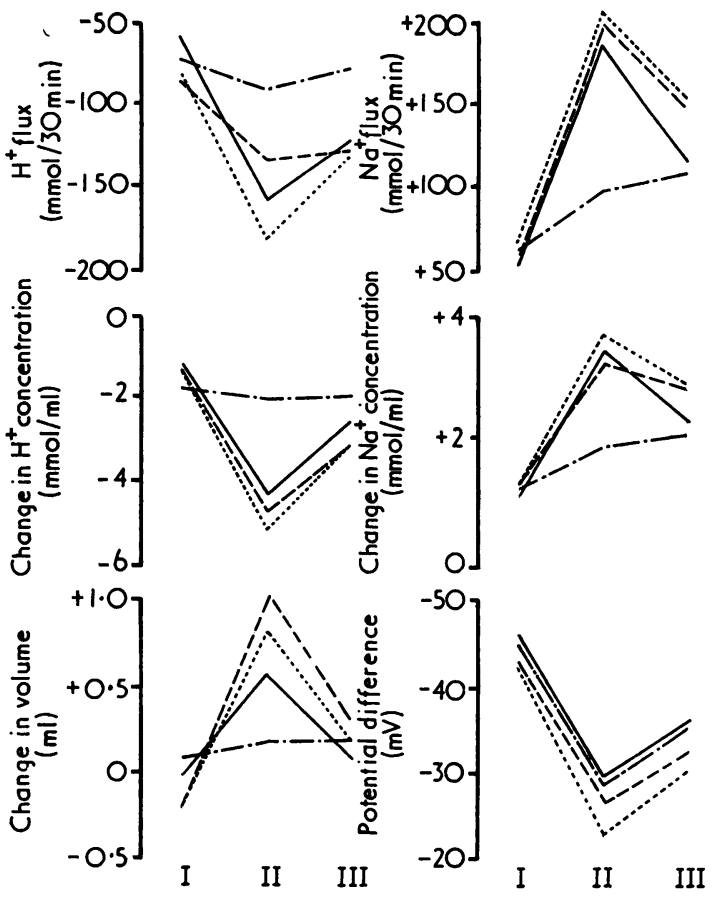

Fig. 2 Changes in volume, ionic concentration and flux (hydrogen and sodium), and transmucosal potential difference during three 30 minute periods in four dogs. Standard acid was used in period I and III and taurocholate in period II. Each line represents the mean of 12 experiments: control infusion ----; $\mathrm{H}_{1}$ antagonist $-; \mathrm{H}_{2}$ antagonist $\ldots \ldots ; \mathrm{H}_{1}+\mathrm{H}_{2}$ antagonists..- -

increased (overall mean of $+1.0 \mathrm{ml}$ )-a difference of 1.2 compared with period I $(P<0.01)$. In period III there was a small overall gain of $+0.3 \mathrm{ml}$.

There was a decrease in the hydrogen ion concentration in each period; in the first period this was

Table Overall mean changes in volume, hydrogen ion concentration and flux, sodium ion concentration and flux, and transmucosal potential difference

\begin{tabular}{|c|c|c|c|c|c|c|c|c|c|c|c|c|c|c|c|c|c|c|}
\hline \multirow[b]{2}{*}{$\begin{array}{l}\text { Treatment } \\
\text { Control } \\
\mathrm{H}_{2} \text { antagonism } \\
\mathrm{H}_{1} \text { antagonism } \\
\mathrm{H}_{1} \text { and } \mathrm{H}_{2}\end{array}$} & \multicolumn{3}{|c|}{ Volume change $(\mathrm{ml})$} & \multicolumn{3}{|c|}{$\begin{array}{l}\text { Change in } H^{+} \\
\text {concentration } \\
(\mu \mathrm{mol} / \mathrm{ml})\end{array}$} & \multicolumn{3}{|c|}{$\begin{array}{l}H^{+} \text {flux } \\
(\mu \text { mol/30 min })\end{array}$} & \multicolumn{3}{|c|}{$\begin{array}{l}\text { Change in } \mathrm{Na}^{+} \\
\text {concentration } \\
(\mu \mathrm{mol} / \mathrm{ml})\end{array}$} & \multicolumn{3}{|c|}{$\begin{array}{l}\mathrm{Na}^{+} \text {flux } \\
(\mu \mathrm{mol} / 30 \mathrm{~min})\end{array}$} & \multicolumn{3}{|c|}{$\begin{array}{l}\text { Potential } \\
\text { difference }\end{array}$} \\
\hline & $\begin{array}{l}I \\
-0.2 \\
-0.2 \\
0 \\
-0.1\end{array}$ & $\begin{array}{l}I I \\
+1.0 \\
+0.8 \\
+0.6 \\
+0.2\end{array}$ & $\begin{array}{l}I I I \\
+0 \cdot 3 \\
+0 \cdot 2 \\
+0 \cdot 1 \\
+0 \cdot 2\end{array}$ & $\begin{array}{l}I \\
-1 \cdot 3 \\
-1 \cdot 3 \\
-1 \cdot 2 \\
-1 \cdot 7\end{array}$ & $\begin{array}{l}I I \\
-4 \cdot 7 \\
-5 \cdot 1 \\
-4 \cdot 3 \\
-2 \cdot 0\end{array}$ & $\begin{array}{l}I I I \\
-3 \cdot 1 \\
-3 \cdot 1 \\
-2 \cdot 5 \\
-1 \cdot 9\end{array}$ & $\begin{array}{l}I \\
-84 \\
-81 \\
-59 \\
-72\end{array}$ & $\begin{array}{l}I I \\
-131 \\
-179 \\
-156 \\
-87\end{array}$ & $\begin{array}{l}I I I \\
-126 \\
-130 \\
-120 \\
-77\end{array}$ & $\begin{array}{l}I \\
+1 \cdot 3 \\
+1 \cdot 3 \\
+1 \cdot 1 \\
+1 \cdot 2\end{array}$ & $\begin{array}{l}I I \\
+3 \cdot 3 \\
+3 \cdot 7 \\
+3 \cdot 4 \\
+1 \cdot 9\end{array}$ & $\begin{array}{l}I I I \\
+2 \cdot 8 \\
+2 \cdot 9 \\
+2 \cdot 3 \\
+2 \cdot 1\end{array}$ & $\begin{array}{l}I \\
+61 \\
+67 \\
+55 \\
+63\end{array}$ & $\begin{array}{l}I I \\
+200 \\
+206 \\
+187 \\
+99\end{array}$ & $\begin{array}{l}I I I \\
+149 \\
+155 \\
+118 \\
+110\end{array}$ & $\begin{array}{l}I \\
-43 \\
-43 \\
-47 \\
-45\end{array}$ & $\begin{array}{l}I I \\
-25 \\
-23 \\
-29 \\
-29\end{array}$ & $\begin{array}{l}I I I \\
-33 \\
-30 \\
-36 \\
-35\end{array}$ \\
\hline
\end{tabular}

Each figure is the mean of 12 experiments-three in each of four dogs with Heidenhain pouches. Series of 12 experiments were conducted during the control infusion of normal saline $(C), H_{1}$ receptor antagonism $\left(H_{1}\right), H_{2}$ receptor antagonism only $\left(H_{2}\right)$, and combined receptor antagonism $\left(\mathrm{H}_{1}+\mathbf{H}_{2}\right)$. A standard acid solution was used in periods I and III and a taurocholate solution in period II. 
small (overall mean $-1.3 \mu \mathrm{M} / \mathrm{ml}$ ) but with bile the fall was greater (overall mean $-4.7 \mu \mathrm{M} / \mathrm{ml}$ ), which differed significantly from period I $(P<0.05)$. These changes in concentration reverted towards control values in the subsequent period. Changes in volume and hydrogen ion concentrations are reflected in the calculated hydrogen ion flux; during period I there was a loss of hydrogen ion (overall mean flux of $-84 \mu \mathrm{M} / 30 \mathrm{~min}$ ) which increased to $-131 \mu \mathrm{M} / 30 \mathrm{~min}$ during the bile period.

An increase in the sodium ion concentration occurred during each period; in period I the overall mean increase was $+1 \cdot 3 \mu \mathrm{M} / \mathrm{ml}$ but with bile in II it was $+3.3 \mu \mathrm{M} / \mathrm{ml}(\mathrm{P}<0.025)$. During period III the increase in concentration was less than in period II. The changes in sodium ion flux in periods I and II followed a pattern similar to those described for changes in sodium ion concentration $(61 \mu \mathrm{M} / 30$ min compared with $200 \mu \mathrm{M} / 30 \mathrm{~min}$; $\mathrm{P}<0.025$ ).

The transmucosal potential difference remained steady throughout period I (overall mean of $-43 \mathrm{mV}$ ) but with taurocholate in period II there was an immediate fall of about $-16 \mathrm{mV}$ to a lower value (overall mean $-26.6 \mathrm{mV}, P$ 0.02). During period III there was partial recovery to a mean value of $-33 \mathrm{mV}$.

\section{EXPERIMENTS IN WHICH BOTH MEPYRA-}

MINE MALEATE AND METIAMIDE WERE

GIVEN

Results in these experiments differed markedly from those already described. With bile in period II the usual changes either did not occur or were much smaller. There was no significant change in the volume of fluid recovered from the pouch (with the exception of $\operatorname{dog} \mathrm{A}$ ). The change in $\mathrm{H}^{+}$concentration in period II did not differ significantly from that in period I. The corresponding values for $\mathrm{H}^{+}$and $\mathrm{Na}^{+}$flux and $\mathrm{Na}^{+}$concentration in period II did not differ significantly from the first period. Results from the first period did not differ significantly in any respect from those in the experiments already described.

Changes in the transmucosal potential difference were similar to those which have already been described; the usual fall of $16 \mathrm{mV}$ occurred in period II with exposure to bile.

\section{HISTAMINE MEASUREMENTS}

In control experiments the histamine content of fluid drained from the pouch at the end of period I was $0.030 \mu \mathrm{g} / \mathrm{ml}$ (mean from six experiments), range 0.002 to 0.072 , but at the end of period II the mean histamine content had increased to $0.066 \mu \mathrm{g} / \mathrm{ml}$ (range 0.040 to 0.102 and in each of the experiments the hstamine concentration increased with bile. The comparable values from six experiments where $\mathrm{H}_{1}$ and $\mathrm{H}_{2}$ antagonists were given together were $0.055 \mu \mathrm{g} / \mathrm{ml}$ (range 0.033 to 0.099 ) and $0.058 \mu \mathrm{g} / \mathrm{ml}$ (range 0.045 to 0.07).

\section{Discussion}

The combined effect of $\mathrm{H}_{1}$ and $\mathrm{H}_{2}$ histamine antagonists reduces or abolishes changes in the volume and ionic fluxes produced by sodium taurocholate; this finding would strongly suggest that changes in the ionic permeability of gastric mucosa after exposure to bile acid are mediated by histamine. However, the resting transmucosal potential difference and its response to damage are unchanged by $\mathrm{H}_{1}$ and $\mathrm{H}_{2}$ antagonists, either alone or in combination. In previous work the cardiovascular effects of histamine have been blocked by combined action of both $\mathrm{H}_{1}$ and $\mathrm{H}_{2}$ receptor antagonists, although some effect was demonstrated with mepyramine alone (Black et al., 1975). Our failure to show any effect with $\mathrm{H}_{1}$ receptor antagonists alone may be related to the sensitivity of our model.

During the experiments we tried to achieve minimal damage to the gastric mucosa for each dog. We have found that the protective effect of combined histamine antagonists may be overcome by concentrations of taurocholate greater than required to produce minimal damage. A further critical factor was the dose of the $\mathrm{H}_{1}$ antagonist (mepyramine maleate) given before damage. Reduction of the dose below $10 \mathrm{mg} / \mathrm{kg}$ was associated with inconsistent results, while increasing the dose above this level produced side-effects of tremor and anxiety.

It has been suggested that mucosal damage is produced by the back diffusion of hydrogen ions across the disrupted mucosal barrier, and that detergents, such as bile acids, merely damage the lipoprotein layer of superficial cells facilitating hydrogen ion back diffusion. The mucosal oedema and flux of sodium rich fluid into the lumen were considered to be the result of mast cell histamine release by the hydrogen ions (Davenport, 1972). On this basis, histamine antagonism would not be expected to abolish hydrogen ion back diffusion. Our results show that the hydrogen ion flux produced by taurocholate was abolished when both histamine antagonists were used. There are two possible explanations for this finding; firstly, true hydrogen ion flux may not occur, and the loss of hydrogen ion from the lumen may be due to neutralisation by fluid passing from the mucosa into the lumen. Another possibility is that hydrogen ion flux may be the result and not the cause of histamine 


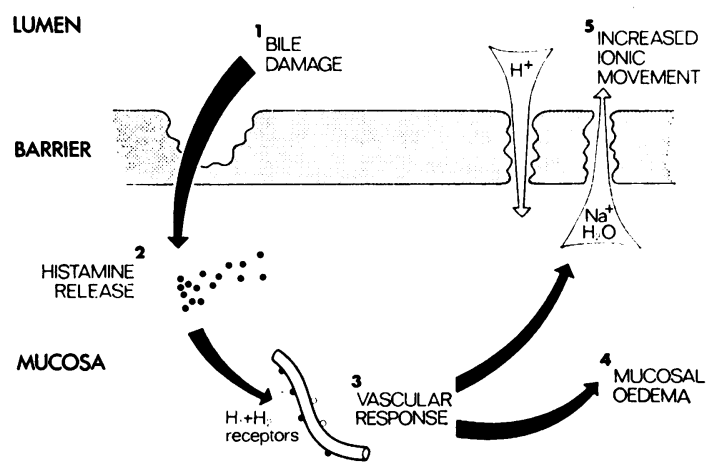

Fig. 3 A hypothesis to explain the mechanisms which may be involved in bile damage to gastric mucosa. Bile acids release histamine, which acts on both $H_{1}$ and $\mathrm{H}_{2}$ receptors on mucosal blood vessels, causing mucosal oedema and increased ionic diffusion across the mucosa.

release. The data presented do not warrant definite conclusions about the mechanism of mucosal damage. One explanation would be to suggest that histamine is released by the damaging agent, and the subsequent interaction between histamine and $\mathrm{H}_{1}$ and $\mathrm{H}_{2}$ receptors on mucosal blood vessels may in some way be responsible for the increased ionic flux which occurs during mucosal damage (Fig. 3). The histamine may be derived from mast cells or other sources in the mucosa. Our measurements of histamine in the pouch fluid show that in control experiments the concentration increased on each occasion with the addition of bile. Changes in $\mathrm{H}^{+}$ flux were net values and it is impossible to distinguish to what extent changes in secretion may affect results. Any tissue histamine released by bile did not produce measurable secretion of $\mathrm{H}^{+}$and values from metiamide experiments were similar to controls. This would suggest that parietal cell secretion played little part in the experiment for one would expect this dose of metiamide to block the parietal cell response to histamine.

During experiments where both $\mathrm{H}_{1}$ and $\mathrm{H}_{2}$ antagonists were given, the histamine concentration in pouch fluid was significantly higher than control values for period $\mathrm{I}$, but did not increase with bile. The high values in period I during infusion of histamine antagonists may be due to release of histamine from tissue by the antagonists. $\mathrm{H}_{1}$ antihistamines have been shown to release histamine from both animal and human tissue in vitro (Arunlakshana, 1953; Mota and Da Silva, 1960); they also reduce breakdown of histamine by reducing the activity of enzymes involved in its catabolism (Cohn and Wynn, 1968). The absence of any increase with bile may indicate that histamine which would normally be released by bile had already been displaced by antihistamines. The concentration of histamine during the bile period in control experiments did not differ significantly from the acid and bile periods in experiments with histamine antagonists. Since histamine concentrations were high in these three periods, differences in ionic fluxes were probably caused by antagonists blocking the histamine effect in those experiments where $\mathrm{H}_{1}$ and $\mathrm{H}_{2}$ antagonists were given.

In most previous work, damage to the gastric mucosa has been accompanied by both a fall in the potential difference and an increase in the movement of ions across the mucosa (Davenport, 1964; Chvasta and Cooke, 1971). Our results show a clear separation between these two parameters. The precise interrelationship between potential difference and physiological or pathological factors affecting function or structure in the stomach are unknown. Transmucosal potential difference is located in the mucosa (Villegas, 1962) and has in the past been linked with acid secretion (Crane et al., 1943; Rehm, 1962; Andersson and Grossman, 1966). The active transport of ions, the permeability of the mucosal and serosal surfaces of epithelial cells to ions, and the differences between intracellular and extracellular concentrations of ions are some of the factors that may be important in the maintenance of the transmucosal potential difference. Hogben in 1955 suggested that gastric mucosal potential difference originated in the active transport of chloride ions by the mucosa, while Davenport in 1964 and Cummins and Vaughan in 1965 suggested that potential difference was dependent on sodium gradients across the mucosa. Our results simply show that changes in the transmucosal potential difference may occur independently of changes in sodium or hydrogen ion fluxes across mucosa. The fall in potential difference which follows exposure to taurocholate may be related to a direct effect of the damaging agent on the surface epithelial cell, which is independent of histamine release.

The combined use of $\mathrm{H}_{1}$ and $\mathrm{H}_{2}$ receptor antagonists has potential therapeutic implications in the treatment of gastritis and gastric ulcer. However, at present, side-effects of conventional antihistamines are unacceptable at high dosage.

\section{Conclusion}

In four canine Heidenhain pouches the net fluxes of $\mathrm{H}^{+}$and $\mathrm{Na}^{+}$have been examined before, during, and after instillation of sodium taurocholate into the pouch. These experiments were conducted in animals given $\mathrm{H}_{1}$ (mepyramine maleate) and $\mathrm{H}_{2}$ (metiamide) histamine antagonists, alone and in 
combination. Control experiments without antagonists were also conducted. In control experiments, as well as those using the histamine antagonists separately, the usual sequence of events followed exposure to taurocholate-that is, a gain in the volume of the solution in the pouch and an increase in the fluxes of $\mathrm{Na}^{+}$and $\mathrm{H}^{+}$across the mucosa. In experiments in which $\mathrm{H}_{1}$ and $\mathrm{H}_{2}$ histamine antagonists were used in combination, taurocholate had very little effect on the ionic fluxes of $\mathrm{H}^{+}$and $\mathrm{Na}^{+}$, suggesting that changes in the ionic permeability of the gastric mucosal barrier are mediated by histamine through both $\mathrm{H}_{1}$ and $\mathrm{H}_{2}$ receptor sites. The transmucosal potential difference fell during the bile period in all of the experiments, including those where $\mathrm{H}_{1}$ and $\mathrm{H}_{2}$ antagonists were used together. Histamine concentrations in the pouch fluid increased twofold during the bile period in control experiments, but were raised in both the prebile and bile periods in experiments where $\mathrm{H}_{1}$ and $\mathrm{H}_{2}$ antagonists were used in combination.

\section{References}

Arunlakshana, O. (1953). Histamine release by antihistamines. Journal of Physiology, 119, 47P-48P.

Augur, N. A. Jr (1970). Gastric mucosal blood flow following damage by ethanol, acetic acid or aspirin. Gastroenterology, 58, 311-320.

Black, J. W., Duncan, W. A. M., Durant, C. J., Ganellin, C. R., and Parsons, E. M. (1972). Definition and antagonism of histamine $\mathrm{H}_{2}$-receptors. Nature, 236, 385-390.

Black, J. W., Owen, D. A. A., and Parsons, M. E. (1975). An analysis of the depressor responses to histamine in the cat and dog: involvement of both $\mathrm{H}_{1}$ and $\mathrm{H}_{2}$ receptors. British Journal of Pharmacology, 54, 319-324.

Chvasta, T. E., and Cooke, A. R. (1972). The effect of several ulcerogenic drugs on the canine gastric mucosal barrier. Journal of Laboratory and Clinical Medicine, 79, 302-315.

Cohn, V. H., and Wynn, W. (1968). Inhibition of histamine metabolism by antihistamine drugs. Federation Proceedings, 27, 243.

Cummins, J. T., and Vaughan, B. E. (1965). Ionic relationships of the bioelectrogenic mechanism in isolated rat stomach. Biochimica et Biophysica Acta, 94, 280-292.
Davenport, H. W. (1964). Gastric mucosal injury by fatty and acetylsalicylic acids. Gastroenterology, 46, 245-253.

Davenport, H. W. (1972). The gastric mucosal barrier. Digestion, 5, 162-165.

Flynn, S. B., and Owen, D. A. A. (1975). Histamine receptors in peripheral vascular beds in the cat. British Journal of Pharmacology, 55, 181-188.

Fromm, D., Schwartz, J. H., and Quijano, R. (1975). Transport of hydrogen; ion and other electrolytes across isolated gastric mucosa of the rabbit. American Journal of Physiology, 228, 166-171.

Guth, P. H., and Hall, P. (1966). Microcirculatory and mast cell changes in restraint-induced gastric ulcer. Gastroenterology, 50, 562-570.

Hogben, C. A. M. (1955). Active transport of chloride by isolated frog gastric epithelium: origin of the gastric mucosal potential. American Journal of Physiology, 180, 641-649.

Jacobson, E. D., and Chang, A. C. K. (1969). Comparison of gastrin and histamine on gastric mucosal blood flow. Proceedings of the Society for Experimental Biology and Medicine, 130, 484-486.

Johnson, L. R. (1966). Histamine liberation by gastric mucosa of pylorus ligated rats damaged by acetic or salicylic acids. Proceedings of the Society for Experimental Biology and Medicine, 121, 384-386.

Johnson, L. R. (1968). Source of the histamine release during damage to the gastric mucosa by acetic acid. Gastroenterology, 54, 8-15.

Moody, F. G., and Davis, W. L. (1970). Hydrogen and sodium permeation of canine gastric mucosa during histamine and sodium thiocyanate administration. Gastroenterology, 59, 350-357.

Mota, I., and Da Silva, W. 'D. (1960). The anti-anaphylactic and histamine releasing properties of the antihistamines. Their effect on the mast cells. British Journal of Pharmacology and Chemotherapy, 15, 396-404.

Reed, J. D., and Sanders, D. J. (1975). Does histamine have two vasodilator actions on the gastric mucosa. Agents Actions, 5, 1-3.

Reed, J. D., and Smy, J. R. (1971). Mechanisms relating gastric acid secretion and mucosal blood flow during gastrin and histamine stimulation. Journal of Physiology, 219, 571-585.

Shore, P. A., Burkhalter, A., and Cohn, V. H. (1959). A method for the fluorometric assay of histamine in tissues. Journal of Pharmacology and Experimental Therapeutics, 127, 182-186.

Villegas, L. (1962). Cellular location of the electrical potential difference in frog gastric mucosa. Biochimica et Biophysica Acta, 64, 359-367. 